\title{
Hiv og aids i Russland: regimedynamikk og respons
}

\author{
Julie Helseth Udal` \\ Universitetet i Oslo
}

\begin{abstract}
HIV and AIDS in Russia: Regime Dynamics and Response
Over the last two decades, the number of persons living with HIV in Russia has increased dramatically. According to WHO criteria, Russia is now facing a generalized HIV epidemic. This article analyzes how regime dynamics have influenced Russia's capacity to build a domestic response to the epidemic. Putin's cultural conservative turn in 2012 may have negatively affected the regime's ability to curb the spread of HIV. Evidence collected for this study indicates that three developments in particular have contributed to this. The first is the introduction of legislation aimed at reducing foreign involvement in Russia, which has weakened civil society as the main provider of prevention programs and services to key populations, and has forced global agencies to leave the country. Secondly, the increasing use of value-based conservative rhetoric after 2012 has meant better access to state structures, policy crafting and governmental funding for actors opposed to conventional methods of preventing HIV. Lastly, Putin's post-2012 cultural conception of the state has served to entrench Russian neopatrimonialism. As neopatrimonialism creates conditions unfavorable to successful implementation of reforms, including those necessary to deal with the ongoing epidemic, its stabilization may have assisted inaction as regards HIV.
\end{abstract}

Keywords: Russia, public health, HIV/AIDS, civil society, neopatrimonialism

Siden slutten av 1990-tallet har antallet hiv-smittede i Russland økt kraftig. ØstEuropa og Sentral-Asia er nå den eneste regionen ${ }^{1}$ i verden hvor antallet nye hivinfeksjoner øker, og 75 prosent av alle positive tester registrert her i 2017, var russiske (UNAIDS, 2018a, s. 241). I andre deler av verden har smitteratene falt betydelig de siste 10-15 årene, hovedsakelig gjennom informasjon, effektive medisiner og bred behandlingsdekning. Russiske myndigheter har aldri lykkes med å introdusere denne typen tiltak, og etter at den første hiv-diagnosen ble stilt i Moskva i 1986, har rundt 1,3 millioner russiske innbyggere testet positivt for hiv (Det føderale aidssenteret, 2018).

${ }^{1}$ UNAIDS behandler Øst-Europa og Sentral-Asia som én region.

\footnotetext{
^Kontaktinformasjon: Julie Helseth Udal, epost: julie.helseth.udal@gmail.com 
Mørketallene er trolig store, og det er anslått at kun halvparten av alle hiv-smittede i landet kjenner sin smittestatus (Levi et al., 2016, s. 5). Hiv-infeksjon er nå utbredt $\mathrm{i}$ alle befolkningslag, og ifølge kriterier fra Verdens helseorganisasjon (WHO) har Russland en generalisert hiv-epidemi. ${ }^{2}$

Dagens epidemi kan ikke sies å ha kommet som noen stor overraskelse. Både russiske og internasjonale helseaktører har i over to tiår understreket alvoret i situasjonen i Russland (Ingram, 1996; NIC, 2002, s. 12; UNAIDS, 2008). Russiske myndigheter har imidlertid ikke sørget for effektive nasjonale tiltak. Paradoksalt nok har de i samme periode gitt betydelige summer til internasjonal hiv-/aidsbistand.

For at myndighetene skal få epidemien under kontroll, vil en reform av russisk hiv-politikk trolig være nødvendig. ${ }^{3}$ Moderniseringsprogrammer og -reformer innen helsesektoren har vært en prioritet siden Putin kom til makten i 2000, men resultatene har ikke stått i forhold til målsettingene (Shishkin, 2013, s. 2). Russlands politiske system og innviklede maktstrukturer giør at det er komplisert å innføre reelle reformer (Gelman \& Starodoubtsev, 2016). At infeksjonen i Russland stadig forstås som et moralsk problem, utgjør en ytterligere hindring for hiv-reformer (Pape, 2014).

Skiftninger i økonomien og det politiske klimaet kan også ha påvirket regimets evne til å stanse smittespredningen. Medvedev promoterte i sin presidentperiode (2008-2012) «modernisering», blant annet gjennom demokratisering og internasjonalisering. Russlands politiske kurs tok deretter en konservativ vending med gjenvalget av Putin i 2012. Globalisering og utenlandsk innblanding har siden blitt trukket fram av landets ledelse som trusler mot russisk kultur, moral og stabilitet. Regimet har gjennom denne typen argumentasjon befestet sin posisjon som forsvarer av tradisjonelle verdier, med konsekvenser også for politikkutforming (Hale, 2015, s. 287; Robinson, 2017, s. 360-361).

I denne artikkelen ser jeg på hvordan russisk regimedynamikk påvirker hiv-politikk og spredning av hiv i Russland i dag. Mens både epidemiologiske studier av hiv og forskning på russisk regimedynamikk er relativt omfattende, har mindre oppmerksomhet blitt viet sammenhengen mellom de to. Denne artikkelen er dermed et bidrag til et lite utforsket felt og kan forhåpentligvis bidra til økt innsikt på området. ${ }^{4}$

Artikkelen starter med en beskrivelse av det teoretiske rammeverket som ligger til grunn for analysen, samt en redegjørelse for datainnsamlingsmetoder og benyttede analyseverktøy. Deretter følger en kortfattet presentasjon av hiv-epidemiens

\footnotetext{
${ }^{2}$ En generalisert hiv-epidemi er definert som når hiv-infeksjon er solid befestet $\mathrm{i}$ den generelle befolkningen og prevalens av viruset er over 1 prosent blant gravide (WHO, 2013, s. 15). I Russland er 1,2 prosent av befolkningen i alderen 15-49 år hiv-positive, og prevalensen blant gravide har siden 2002 konsekvent overskredet 1 prosent (Det føderale aidssenteret, u.å.; Det føderale aidssenteret, 2018).

${ }^{3}$ Økning i nye hiv-tilfeller i Russland har siden midten av 2000-tallet ligget jevnt på rundt 10-15 prosent årlig (Det føderale aidssenteret, 2018). Utviklingen tyder på at regimets hiv-respons har vært lite effektiv.

${ }^{4}$ Artikkelen bygger på data fra min mastergrad fra Universitetet i Oslo (Udal, 2018).
} 
historie. Den påfølgende delen presenterer utviklingstrekk i russisk hiv-politikk samt den epidemiologiske utviklingen, før artikkelens analysedel drøfter de skisserte utviklingstrekkene i lys av det teoretiske rammeverket. Deretter diskuteres hovedfunnene, før artikkelen avsluttes med noen tanker om sannsynlig videre utvikling av hiv-epidemien og hiv-politikken i Russland.

\section{Teoretisk rammeverk}

\section{Historiske investeringer og hiv-laidsrespons}

I en artikkel om BRIK-land og aids presenterer Eduardo Gómez (2015, s. 318-319) et rammeverk for å forstå hvordan et lands historiske investeringer i internasjonalt helsesamarbeid kan påvirke landets hiv-/aidsrespons: Stater som tradisjonelt har bidratt til internasjonalt helsearbeid, og som opplever at evnen til å opprettholde bistand reduseres, vil, på bakgrunn av sin historiske rolle og den prestisje som ligger i denne, ønske å gjenopprette donorstatusen dersom statsøkonomien bedres. Imidlertid vil slike gjenopptatte bidrag ytes på bekostning av nasjonale helseinvesteringer. Gómez fremhever videre tre momenter som avgjørende for nasjonal håndtering av hiv, nærmere bestemt: i) etablering og oppfølging av statlige hiv-/aidsprogrammer, ii) finansiering av forebyggingstiltak og programmer som sikrer smittede tilgang på antiretroviral behandling (ART), og iii) samarbeid med og finansiering av ikkestatlige hiv-/aidsorganisasjoner (Gómez, 2015, s. 316). Disse momentene, som står i samvirke med hverandre, kan betraktes som et nasjonalt hiv-/aidspolitisk triangel. ${ }^{5}$

Gómez (2015, s. 324) argumenterer for at historiske investeringer har påvirket russisk hiv-/aidsbekjempelse. Sovjetunionen hadde en betydelig donorrolle i globalt helsesamarbeid, men denne rollen kunne ikke opprettholdes av Russland etter unionens oppløsning. Faktisk var Russland nettomottaker av helsebistand gjennom hele 1990-tallet (Twigg, 2010). Rundt årtusenskiftet ble den russiske økonomien betydelig styrket, noe som gjorde det mulig for myndighetene å gjenopprette Sovjetunionens donorrolle (Gómez, 2015, s. 324). Situasjonen innebar i praksis at russiske hiv-/aidsinvesteringer ble kanalisert mot det internasjonale samfunnet, på bekostning av bevilgninger til det nasjonale hiv-/aidstriangelet. Prioriteringen kan ifølge Gómez tolkes som et virkemiddel regimet har anvendt for å gjenopprette bildet av Russland som en supermakt, og for å styrke landets geopolitiske innflytelse, og den fremheves som en forklaring på hvorfor russiske myndigheter ikke har lykkes i å stanse den nasjonale hiv-epidemien (Gómez, 2015, s. 316).

\section{Neopatrimonialisme og et konservativt skifte}

Henry Hale (2015, s. 7-9) hevder at den tradisjonelle tilnærmingen til studier av postsovjetiske politiske systemer ofte reflekterer en underliggende oppfatning av

${ }^{5}$ For en modell over det russiske hiv-/aidspolitiske triangelet vises til Udal (2018, s. 33). 


\section{2 | JULIE HELSETH UDAL}

hvordan politikk bør fungere, med fokus på temaer som valg og politiske partier. Hale argumenterer for at det er viktigere å studere politikken som faktisk utøves, og at nøkkelen til det er det han kaller politikkens "patronistiske dimensjon", hvilket innebærer at individer primært organiserer livene sine rundt personlig utveksling av goder og sanksjoner. Hierarkiske og komplekse bekjentskapsnettverk utgjør bærebjelken i patronistiske samfunn (Hale, 2015, s. 20-21).

Hales tilnærming er beslektet med Neil Robinsons (2017, s. 350), som bruker termen neopatrimonialisme om det russiske systemet, forstått som en styreform der «predominantly personalist politics exist alongside and are interwoven with larger administrative systems that have some features and functions of a modern bureaucratic system». Neopatrimonialisme kjennetegnes altså av en sammenveving av et personalistisk regime som bestemmer reglene for reell tilgang til makt, og en upersonlig stat med formelle strukturer og offisielle regler for makttilgang (Robinson, 2017).

Robinson (2017, s. 351-352) peker videre på at Russlands postsovjetiske utvikling preges av press om å forlate neopatrimonialismen. Under Putins første to presidentperioder (2000-2004 og 2004-2008) sentraliserte han statsmakten og begrenset makten til regionale ledere og oligarker (Taylor, 2011, s. 288). Utviklingen ga økt stabilitet sammenlignet med 1990-tallet, men ikke egentlig en mer velfungerende stat (Taylor, 2011, s. 292-293). Problemet styringseffektivitet versus regimestyrke ble igjen aktuelt fra 2008, da Medvedev tiltrådte som president og Putin ble statsminister. Dette «tandemsystemet» understreket skillet mellom formell og uformell makt, samtidig som behovet for en mer moderne økonomi ble tydeliggjort av den pågående finanskrisen. Moderniseringsdebatten fikk fornyet aktualitet, og Medvedevs presidentperiode (2008-2012) var preget av uttalte ambisjoner om demokratisering og vestliggjøring (INSOR, 2010, s. 10-12; Robinson, 2017, s. 357-358).

Gjenvalget av Putin i 2012 markerte et konservativt skifte (Hale, 2015) som fortsatt preger det eksisterende regimet. Medvedevs moderniseringsplaner ble forlatt og erstattet med kulturell konservatisme og tanken om Russland som en unik sivilisasjon. Resultatet har vært en sementering av neopatrimonialismen og en revitalisering av Putins image framfor forbedret statsstyring (Robinson, 2017, s. 363-364).

\section{Datainnsamlingsmetoder og analyseverktøy}

Kildematerialet benyttet i denne artikkelen, er hovedsakelig hentet fra ulike dokumenter ${ }^{6}$, herunder offisielle russiske strategier, databaser, taler og uttalelser, nyhetsartikler, epidemiologiske rapporter og vitenskapelige artikler. Jeg har også intervjuet fire representanter fra russiske ikke-statlige organisasjoner (NGO-er) som jobber med hiv og aids.

${ }^{6}$ Termen «dokument» refererer her til alle typer tekstmateriale. 
Jeg har benyttet meg av kvalitativ dokumentanalyse av datamateriale som primært er hentet fra nettkilder. En teksttolkning er kun én av mange mulige tolkninger, slik at man ikke kan trekke slutninger ved å analysere dokumenter separat, men må søke konvergens i ulike dokumenter (Bowen, 2009, s. 27-28). For å bedre dokumentautentisitet har jeg etterstrebet å bruke primærkilder og å lese materialet på originalspråket (Bryman, 2016). Bruk av internettressurser har gitt tilgang til et bredt kildeutvalg og forenklet datainnsamlingsprosessen, men har krevd et kontinuerlig vurdering av dokumentenes troverdighet. For eksempel gir russiske hivstatistikker fra ulike kilder forskjellige tall, og fullstendig korrekte russiske hiv-data finnes sannsynligvis ikke. Jeg har valgt å bruke Russlands føderale aidssenter som hovedkilde til russiske hiv-data i denne artikkelen. ${ }^{7}$

De fire intervjuene ble giennomført via Skype eller e-post. ${ }^{8}$ Informantene ble hovedsakeligrekruttertpere-post, men også via Facebookog detrussiskenettsamfunnet VKontakte. Atten russiske ikke-statlige hiv-/aidsorganisasjoner fra syv føderasjonssubjekter ble kontaktet, og disse ble valgt ut på bakgrunn av sitt antatte potensiale til å bidra med ulike erfaringerog perspektiver. Rekrutteringsprosessen varutfordrende, muligens på grunn av det presset mange hiv-/aidsorganisasjoner arbeider under (HRRCenter, 2018), og de potensielt negative konsekvensene av å bli intervjuet. ${ }^{9}$ Seks NGOrepresentanter samtykket til intervju, hvorav to trakk seg før intervjuet fant sted. For å redusere bekymringer for negative konsekvenser ble alle deltakere lovet anonymitet, og de fikk velge om de ønsket intervju per e-post, telefon eller Skype. To foretrakk e-post, og to valgte Skype. Tillatelse til å ta opptak av Skype-intervjuene ble innhentet. Alle intervjuene ble gjennomført på russisk og deretter transkribert til norsk. ${ }^{10}$

\section{Hiv-epidemiens historie}

Hiv var ukjent fram til 1980-tallet, og man vet ikke hvor mange personer som hadde blitt smittet og eventuelt utviklet aids før den tid. Etter gjentatte tilfeller av aggressive krefttyper, sjeldne lungeinfeksjoner og immunsvikttilstander i flere nordamerikanske byer i 1981 forstod man at sykdommene kunne ha en felles årsak. Syndromet ble kalt "ervervet immunsviktsyndrom», forkortet til «aids»" (U.S. Department of Health and Human Services, 2015). De første pasientene var hovedsakelig menn som hadde sex

\footnotetext{
${ }^{7}$ Det føderale aidssenteret er ansvarlig for hiv-overvåking i Russland. Grunnet ineffektive systemer for testing og overvåking antas senterets data å inkludere rundt halvparten av hiv-positive i Russland (Levi et al., 2014, s. 5). Senteret er imidlertid kjent som en relativt autonom institusjon som jevnlig kritiserer myndighetenes hiv-politikk, og det har høyere tall enn det føderale russiske forbruker- og velferdstilsynet (Rospotrebnadzor) og helseministeriet (Rospotrebnadzor, 2018). ${ }^{8}$ Prosjektnummer 60472, Norsk senter for forskningsdata (NSD).

${ }^{9}$ Som fremhevet av lederen i en av NGO-ene, som avslo intervjuforespørselen (e-postkorrespondanse 17.4.2018).

${ }^{10}$ For mer utdypende metodebeskrivelse og diskusjon av denne vises til Udal (2018).

${ }^{11}$ Aids er en forkortelse for "acquired immune deficiency syndrome».
} 
med menn, men i 1983 ble det rapportert at også kvinner hadde blitt syke. Samme år oppdaget forskere ved Pasteur-instituttet i Frankrike viruset de antok forårsaket aids, som viste seg å være identisk med et annet virus oppdaget ved USAs nasjonale kreftinstitutt året etter (Marx, 1984). Viruset ble kalt "hiv» (humant immunsviktvirus). Viruset giør at immunsystemet gradvis svekkes, slik at man innen 5-12 år utvikler aids. Det første behandlingsalternativet, ART, kom på markedet i 1987 (DHHS, 1987) og ga en kortvarig nedbremsing av sykdomsforløpet. I 1996 ble det introdusert en behandling som hindret viruset $\mathrm{i}$ å formere seg. Dermed kunne man hindre både sykdomsutvikling og smitte, selv om man ikke ble kvitt viruset (Frøland, 2017).

Mange hiv-smittede tilhørte marginaliserte befolkningsgrupper, og frykt, stigma og ignoranse drev epidemien til kritiske høyder (Knight, 2008, s. 8-9). I 1996 ble UNAIDS etablert for å styrke FNs globale innsats. Nesten 6 millioner mennesker hadde da dødd av aids, og rundt 30 millioner var hiv-positive (UNAIDS, 1996). Da patenttiden for de nye effektive ART-preparatene utløp, kunne billigere kopipreparater produseres, og flere produsenter godtok etter hvert å senke prisene for lavinntektsland. I 2002 ble Verdensbankens globale fond for å bekjempe aids, tuberkulose og malaria (Det globale fondet) etablert på initiativ fra FNs generalforsamling ( FN, 2001). Siden 2004 har antallet aidsrelaterte dødsfall globalt sunket, og antallet nye infeksjoner er også kraftig redusert. Unntaket er i Øst-Europa og Sentral-Asia, hvor det i perioden 2010-2016 ble registrert betydelige økninger i både nye infeksjoner og dødsfall (UNAIDS, 2018a).

\section{Russisk hiv-politikks historie og epidemiologisk utvikling}

Den kalde krigen og sovjetstatens strenge oppsyn med innbyggerne bidro til at Sovjetunionen lenge var relativt uberørt av hiv (Field, 2004, s. 117). Statlig hiv-overvåking ble ikke igangsatt før i 1986 (Sharma, Lioznov \& DeHovitz, 2008). Da testet kun 246 av over 90000 hiv-screenede positivt for viruset, hovedsakelig utenlandske studenter. Kun 11 prosent var sovjetiske statsborgere, og disse tilhørte i hovedsak marginaliserte befolkningsgrupper. Det sovjetiske helseministeriet tolket screeningresultatene dithen at den generelle befolkningen ikke var i fare, og man regnet med å få virusspredningen raskt under kontroll gjennom tøffe tiltak mot smittede. Blant tiltakene var obligatorisk testing for utenlandske statsborgere med opphold i Sovjetunionen i over tre måneder, deportasjon av alle hiv-positive utenlandske statsborgere, strafferettslig ansvar for forsettlig eller uaktsom virusoverføring og isolering av smittede sovjetborgere i et spesialsykehus i Moskva (Medvedev, 1990a, s. 860-861). Obligatorisk testing av gravide ble innført i 1989, etter flere hiv-tilfeller blant nyfødte. En statlig aidskomité ble samtidig opprettet, det ble annonsert at midler skulle øremerkes produksjon av kondomer og engangsnåler, og aidssentre ble bygget (Medvedev, 1990b, s. 933-934).

I samme periode begynte artikler om hiv/aids å forsvinne fra sovjetiske medisinske tidsskrift (Medvedev, 1990b, s. 933-934). Informasjonskampanjer ble ikke 
giennomført, og dersom hiv ble nevnt i media, ble viruset oftest omtalt som et «vestlig» problem (Pape, 2014, s. 72). Sovjetisk presse spekulerte også i om aids var forårsaket av USA-ledede eksperimenter med biologiske våpen (Qui, 2017). Noe statlig organ for koordinering av hiv-tjenester ble aldri opprettet, og nyetablerte aidssentre ble aldri integrert i primærhelsetjenesten (Sharma et al., 2008). Helsepersonell ble dermed verken eksponert for eller informert om viruset, noe som svekket helsevesenets evne til å nå bredt ut i befolkningen (Bobrik \& Twigg, 2006, s. 16-17). Det vi kan kalle Sovjetunionens "institusjonelle separasjon» av hiv-omsorg, ble videreført i Russland (Pape, 2014). ${ }^{12}$

Effektive statlige programmer lot vente på seg. De første føderale russiske hiv-programmene ble lansert i 1993 og 1996, men disse var kraftig underfinansiert og ikke særlig vellykket (Twigg \& Skolnik, 2005). Før 1995 ble hiv i Russland hovedsakelig overført seksuelt, med lik fordeling mellom heterofil og homofil kontakt (Det føderale aidssenteret, u.å.). Smittemønstrene endret seg imidlertid drastisk da hiv spredte seg til rusmiljøer i siste halvdel av 1990-tallet. Mens kun 6 prosent av nye infeksjoner ble overført via sprøytemisbruk i 1995, var andelen 96 prosent i 2000 (Det føderale aidssenteret, u.å.). I samme periode økte rusmisbruk generelt i Russland, ${ }^{13}$ i takt med 1990-tallets finansielle, politiske og sosiale ustabilitet og som følge av svakere grensekontroll etter Sovjetunionens oppløsning. Den «nordlige» heroinsmuglingsruten, som går fra Afghanistan via Sentral-Asia gjennom Russland, ble en av verdens tyngst trafikkerte og forsynte et økende antall opiatavhengige russere med billig heroin (UNDCP, 2000, s. 58). Situasjonen resulterte i en økning på hele 8139 prosent i totalt antall hiv-smittede i Russland mellom 1995 og 2000 (Det føderale aidssenteret, u.å.). ${ }^{14}$

I et forsøk på å redusere smittespredning blant sprøytemisbrukere ble «Lov om narkotiske stoffer og psykoaktive substanser» vedtatt i 1998. Loven kriminaliserte all narkotikabruk som ikke var foreskrevet av lege (Føderal lov, 1998). Samtidig ble substitusjonsbehandling, som legemiddelassistert rehabilitering (LAR), kriminalisert, stikk i strid med internasjonale anbefalinger. ${ }^{15}$

\footnotetext{
${ }^{12}$ Separasjonen betyr i praksis at hiv-positive behandles på egne sentre. De fleste russiske føderasjonssubjekter har per i dag kun ett slikt aidssenter. Hiv-positive kan derfor ha flere timers reisevei, noe som vanskeliggiør tilgang på rådgivning, testing og behandling. Innbyggere uten dokumenter eller lokalt registreringsstempel har ikke rett til behandling på sentrene. En av mine respondenter, som kommer fra en NGO som jobber med rusmisbrukere, trakk fram registrerings- og dokumentkravet som et sentralt problem (intervju 030103, 2018).

${ }^{13}$ Mellom 1992 og 2000 økte insidensen av rusmisbruk i Russland fra 2,5 til 50,7 per 100000 innbyggere (Rosstat, 2010). UNDCP estimerte at 0,9 prosent av den russiske befolkningen brukte narkotika ved årtusenskiftet (2000, s. 185).

${ }^{14}$ Antallet hiv-smittede i Russland økte fra 1090 personer i 1995 til 89808 personer i 2000. Totale smittetall inkluderer også døde.

${ }^{15}$ Legemiddelassistert rehabilitering (LAR) innebærer at opioider inngår i behandlingsopplegget ved opioidavhengighet, og det er vist å redusere dødelighet, øke livskvalitet, redusere smittespredning og øke brukeres sjanse for å motta ART (OUS, 2018).
} 


\section{6 | JULIE HELSETH UDAL}

Først i 2001 ble det mer omfattende statlige programmet «Anti-hiv/aids» vedtatt (Helseministeriet, 2001). Programmet var imidlertid underfinansiert, og måloppnåelsen var lav. I løpet av programmets aktive periode (2002-2006) ble antall smittede mer enn doblet (Det føderale aidssenteret, u.å.). Putin refererte for første gang offentlig til den gryende hiv-epidemien i 2003, i sin årlige tale om nasjonens tilstand. Han adresserte da Russlands nedadgående demografiske trend og bemerket hvordan "spredningen av såkalte 'nye' epidemier, inkludert rusavhengighet og aids, bare giør situasjonen verre» (Putin, 2003). Putin la ikke fram noen nye tiltak for å redusere smitteratene, som da var nesten nidoblet siden han overtok presidentvervet. Til tross for referansen til rusavhengighet som en "ny» epidemi var sprøytemisbrukere fortsatt ignorert, og støtte til marginaliserte befolkningsgrupper kom i hovedsak fra sivilsamfunnet. Russland hadde i 2005 rundt 300 aktive ikke-statlige hiv-/aidsorganisasjoner (Pape, 2014).

Signaler om et mulig politisk skifte kom i 2006, da Putin under et møte med Føderasjonsrådet holdt en tale om hiv. Han etterlyste samarbeid mellom ulike instanser og en ny statlig strategi (Putin, 2006). «Anti-hiv/aids»-programmet var på dette tidspunktet inne i sitt siste år. Tre måneder etter talen var Russland vertskap for et G8-toppmøte, hvor infeksjonssykdommer for første gang var hovedprioritet, og det på russisk initiativ (Fight Against Infectious Diseases, 2006; Kirton, Kulik \& Bracht, 2014, s. 155). Etter Putins tale i Føderasjonsrådet og G8-møtet fikk hiv forbigående politisk oppmerksomhet i Russland, og det ble blant annet opprettet en statlig aidskommisjon (Pape, 2014). Økt politisk bevissthet var imidlertid ikke nok til å få en ny strategi på banen, og det totale russiske smittetallet bikket høsten 2008 en halv million (Det føderale aidssenteret, u.å.). Vadim Pokrovskij, leder for Russlands føderale aidssenter, sa senere at han ikke kjente til at aidskommisjonen opprettet i 2006, hadde avholdt et eneste møte, og han kritiserte også manglende samarbeid mellom relevante statlige aktører og finansieringskutt til hiv-/aidsprogrammer (Aleksejev, 2010). Politisk engasjement rundt hiv i Russland hadde tydelig avtatt på 2010-tallet (Pape, 2014).

I oktober 2016 ble den første russiske hiv-strategien på femten år vedtatt. Rundt 1,1 millioner russere hadde da testet positivt for hiv, og nesten en kvart million var døde av aids (Det føderale aidssenteret, 2016). Strategiens overordnede målsetting er å redusere antallet nye hiv-infeksjoner og redusere aidsdødelighet (Regjeringen, 2016, s. 5). Strategien har blitt gjenstand for kritikk fra eksperthold, blant annet for ikke å inkludere WHOs nyeste retningslinjer for behandling, manglende fokus på nøkkelgrupper og manglende finansieringsinformasjon (Clark, 2016). I 2017 rapporterte det russiske nyhetsbyrået RBK at helseministeriet hadde foreslått å sette av 70 milliarder rubler til å gjennomføre strategien, men at finansministeriet hadde avvist forslaget (Zvezdina, 2017). Siden er det lite informasjon om strategiens finansiering eller resultater som er blitt formidlet i russiske medier. Noen umiddelbar virkning kan uansett ikke observeres. Ifølge epidemiologiske oppdateringer har antallet positive russiske hiv-tester økt til ca. 1,3 millioner, mens antallet aidsrelaterte dødsfall har nådd 310000 . Heteroseksuell smitte utgjorde 54 prosent av nye hiv-tilfeller 
i 2017. Det er fremdeles en betydelig andel virusoverføring gjennom sprøytemisbruk (44 prosent), mens homoseksuell smitteoverføring er sjelden (2 prosent) (Det føderale aidssenteret, 2018).

Til tross for at effektiv medikamentell behandling hindrer smittespredning og derfor er det mest effektive hiv-forebyggende tiltaket, har Russland aldri prioritert produksjon av ART. Dermed er behandlingskostnadene betydelig høyere i Russland enn i mange andre land. Til illustrasjon kostet behandling per person i ett år med anbefalte medikamenter 2687 USD i Russland i 2015, mens tilsvarende behandling i Ukraina kostet 110 USD (UNAIDS, 2016a, s. 178). Det har dessuten vært forsyningsproblemer. For eksempel førte avhengighet av utenlandskprodusert ART kombinert med økonomiske nedgangstider og fallende rubelkurs fra 2014 til landsdekkende ART-mangel i 2017 (Boronov, 2017). I 2018 mottok 38 prosent av hivpositive i Russland ART (Det føderale aidssenteret, 2018).

\section{Analyse}

I det følgende vil jeg knytte utviklingstrekkene skissert over, til artikkelens teoretiske rammeverk. Selv om mange faktorer påvirket hiv-/aidsarbeidet i Russland negativt også i Putins to første presidentperioder, vil jeg argumentere for at vesentlige endringer særlig fant sted fra Medvedevs presidentperiode til Putins tredje presidentperiode. ${ }^{16}$ Fokuset $\mathrm{i}$ analysen vil derfor være på forskjeller mellom disse to periodene samt på konsekvenser av gjenvalget av Putin i 2012 for russisk hiv-politikk.

\section{Medvedev (2008-2012): modernisering}

Til tross for den økonomiske krisen som traff Russland i 2008, intensiverte myndighetene i løpet av Medvedevs presidentperiode donasjonene til global hiv-/aidsbistand. Mellom 2008 og 2010 bidro Russland med 141,3 millioner USD til Det globale fondet, et beløp som overgikk alle tidligere og senere russiske donasjoner. I 2010 ble ytterligere 60 millioner USD lovet (Det globale fondet, 2010; Det globale fondet, 2017). Lavere beløp ble også tildelt andre internasjonale organisasjoner, for eksempel ble 5 millioner USD gitt til UNAIDS (UNAIDS, 2018b). Samtidig ble ingen nye strategier eller programmer implementert på hjemmebane. De betydelige donasjonene til globalt hiv-/aidsarbeid kombinert med manglende innsats nasjonalt i perioden 20082012 underbygger Gómez' teori om at russiske bidrag til global hiv-/aidsbistand kan ha gått på bekostning av investeringer i det nasjonale hiv-/aidstriangelet.

Gómez' forklaring synes imidlertid ikke å være eneste årsak til manglende håndtering av hiv/aids mellom 2008 og 2012. Russisk regimedynamikk kan også ha

\footnotetext{
${ }^{16}$ Gómez skiller i sin artikkel ikke tydelig mellom Putins to første presidentperioder (2000-2004, 2004-2008), Medvedevs presidentperiode (2008-2012) og Putins tredje presidentperiode (20122018).
} 


\section{8 | JULIE HELSETH UDAL}

bidratt. Medvedev argumenterte for modernisering i form av demokratisering og internasjonalisering, men arvet kun den formelle makten i landet. Selv om det fulgte et visst politisk handlingsrom med presidentposten, måtte han fremdeles håndtere utfordringene knyttet til Putins uformelle makt og de personalistiske nettverkene som gjennomsyrer det russiske politiske systemet (Hale, 2015; Robinson, 2017). Denne dynamikken begrenset Medvedevs muligheter til å få gjennomslag for sin politikk, og han hadde trolig liten reell mulighet til å reformere Russlands tilnærming til hiv-problematikken uten støtte fra uformelle deler av maktapparatet.

Myndighetene hadde fra tidlig 2000-tall gradvis økt sin tilsynsmakt over sivile aktører i Russland, særlig gjennom «NGO-loven» ${ }^{17}$ fra 2006. Inntil 2012 kunne imidlertid sivile aktører motta finansiell støtte fra andre kilder enn myndighetene uten betydelig risiko, også fra utlandet. Internasjonale hiv-/aidsprosjekter i Russland, ledet av organisasjoner som UNAIDS, UNICEF og OSIAF/OSF, var også godtatt. I tillegg betød Russlands verdensbankstatus som middelinntektsland at landet kvalifiserte til tilskudd fra Det globale fondet. Mellom 2008 og 2012 mottok Russland tre hiv-/aidstilskudd herfra, verdt totalt 247 millioner USD (Det globale fondet, 2017). Tilskuddene finansierte hovedsakelig russiske NGO-er og forebyggingsprosjekter rettet mot marginaliserte nøkkelgrupper. Det kan på denne bakgrunn synes som at internasjonalisering, særlig i form av kontakt mellom russiske og internasjonale aktører, i praksis kan ha vært den viktigste hiv-politikken Medvedev førte.

\section{Putin (2012-2018): stabilisering av neopatrimonialisme gjennom kulturell konservatisme}

Internasjonaliseringsfokuset fikk en bråstopp med gjenvalget av Putin i 2012. Endringen i fokus ga seg blant annet utslag i kraftige kutt i russiske donasjoner til internasjonal hiv-/aidsbistand. Etter å ha betalt summen som ble lovet til Det globale fondet i 2010, trakk Russland seg ut av samarbeidet og har siden ikke vært å finne på donorlisten (Det globale fondet, 2017). Bidragene til WHO og UNAIDS har blitt opprettholdt, men de totale overføringene til hiv-/aidsbistand er betydelig lavere enn donasjonene under Medvedevs presidentperiode. ${ }^{18}$ Ambisjoner om å gjenopprette og opprettholde en historisk donorrolle kan trolig derfor ikke forklare den manglende håndteringen av hiv/aids innad i Russland etter 2012.

\footnotetext{
${ }^{17}$ Føderal lov (2006) nr. 18, "Endringer til enkelte lovgivende handlinger i den russiske føderasjon». Loven ga blant annet myndighetene tillatelse til å sende representanter til organisasjoners møter og påla dem å fullføre nye registreringsdokumenter med detaljert informasjon over medlemmer og sponsorer. Andre pålegg i loven var innrapportering av utenlandske donasjoner og redegjørelse for hvordan pengene ble brukt (Crotty, Hall \& Ljubownikow, 2014, s. 1254).

${ }^{18}$ I perioden $2000-2012$ ble i snitt 15 prosent av Russlands ODA brukt på hiv-/aidsbistand. For årene 2012-2017 var andelen 0,4 prosent (WHO, 2015; WHO, 2017; Det globale fondet, 2017; OECD, 2018; UNAIDS, 2018b).
} 
På hjemmebane har den verdikonservative vendingen gitt seg utslag i at regimet har utsatt det russiske hiv-/aidstriangelet for stadig sterkere press. Presset er hovedsakelig utøvet gjennom kontroll over utenlandsk innblanding i Russland, offisiell motstand mot internasjonale forebyggingsanbefalinger og strengere oppsyn med russiske sivile aktører og deres kontakt med det globale samfunnet. Den viktigste hiv-politikken Medvedev førte, synes med dette å være truet.

Flere internasjonale hjelpeorganisasjoner involvert i hiv-bekjempelse i Russland, har blitt presset ut av landet. I september 2012 måtte USAID forlate Russland etter beskyldninger om forsøk på å påvirke politiske prosesser gjennom tilskuddsordninger. USAID hadde til da brukt 2,7 milliarder USD på prosjekter i Russland (USAID, 2012). I oktober 2012 ble UNICEF bedt om å forlate Russland, angivelig fordi russiske myndigheter ønsket å være en donor til framfor mottaker av FNbistand (Ria Novosti, 2012). Det globale fondet trakk seg ut året etter, offisielt fordi Russland i juli 2013 fikk verdensbankstatus som et høyinntektsland. Fondet hadde siden tidlig 2000-tall vært største sponsor av hiv-/aidsprogrammmer i Russland. Blant konsekvensene av fondets uttrekking var finansieringsstopp til 30 prosjekter rettet mot sprøytemisbrukere (UNAIDS, 2016a, s. 178). Høsten 2015 ble de to stiftelsene OSIAF og OSF, som blant annet hadde prosjekter konsentrert rundt skadereduserende tiltak ${ }^{19}$ i Russland, oppført som «uønskede organisasjoner» (Justisministeriet, 2018b).

I 2012 ble «utenlandsk agent»-loven (121-FZ) innført. ${ }^{20}$ Loven pålegger organisasjoner som mottar utenlandsk finansiering og er involvert $\mathrm{i}$ "politisk aktivitet», å registrere seg som utenlandske agenter. NGO-er som nekter å registrere seg, kan straffes med oppløsning, tvangsregistrering (fra 2014), bøter eller fengsel for organisasjonens ledelse. Registrerte organisasjoner må jevnlig levere inn detaljerte økonomiske rapporter og merke alt sitt materiale med stempelet «utenlandsk agent» (Føderal lov, 2012; Flikke, 2016). I 2015 ble det innført et tillegg til 121-FZ, ${ }^{21}$ hvilket innebærer at organisasjoner som anses som trusler mot russisk nasjonal sikkerhet, kan erklæres uønsket i landet. Uønskede NGO-er har blant annet forbud mot å operere i Russland og mot å finansiere russiske organisasjoner (Gilbert, 2016).

Siden 2016 har tolv ikke-statlige hiv-/aidsorganisasjoner blitt oppført i registeret tilknyttet «utenlandsk agent»-loven (Justisministeriet, 2018a). ${ }^{22}$ Først ut var Omsk-baserte SIBALT, som hadde delt ut brosjyren «LGBT. Menneskerettigheter

\footnotetext{
${ }^{19}$ Skadereduserende tiltak inkluderer vanligvis programmer for utdeling av kondomer, rent brukerutstyr og LAR til sprøytemisbrukere samt ART til hiv-positive i gruppen.

${ }^{20}$ Føderal lov (2012) nr. 121, "Om endringer i lovgivende handlinger i den russiske føderasjon om regulering av aktivitetene til ikke-kommersielle organisasjoner som utfører funksjoner til en utenlandsk agent».

${ }^{21}$ «Om endringer i lovgivende handlinger i den russiske føderasjon» (Føderal lov, 2015).

${ }^{22}$ Fire av de tolv organisasjonene som har blitt registrert som utenlandske agenter, er likvidert som følge av oppføringen. Per 7. desember 2018 inneholdt «utenlandsk agent»-registeret derfor åtte ikke-statlige hiv-/aidsorganisasjoner av totalt 72 oppførte organisasjoner (Justisministeriet, 2018).
} 
i Russland» (SIBALT, 2016). Deretter fulgte Sotsium, en organisasjon som blant annet tilbød rene engangsnåler og kondomer til sprøytemisbrukere i Saratov oblast (Tsjernykh, 2016b). Andrej Rylkov-fondet, Moskvas eneste tilbyder av skadereduserende tiltak, ble deretter registrert, og det samme gjaldt ESVERO, Russlands største nettverk for skadereduserende tiltak. Myndighetenes oppnevnte ekspert konkluderte under rettshøringene med at «NGO-er som Sotsium og ESVERO ødelegger både våre tradisjoner og våre nasjonale verdier», og at organisasjonene måtte anses som "deltakere i en hybridkrig mot Russland» (Vzgljad-info, 2016). Senere samme år led ytterligere fem organisasjoner som tilbød skadereduserende tiltak i henholdsvis Penza, Sverdlovsk og Samara oblast, samme skjebne. Utviklingen fortsatte i 2017 og 2018. Organisasjonen Novoje Vremja fra Sverdlovsk oblast ble først registrert etter at lederen kritiserte russisk hiv-politikk i et intervju med Der Spiegel (Hebel, 2016). Deretter fulgte Vybor, som tilbød skadereduserende tiltak i Altaj kraj, og Fond for helsebeskyttelse og rettigheter fra Tatarstan, som jobbet med rettslig beskyttelse av hiv-positive (Interfax, 2018).

Et av mine intervjuobjekter snakket om hvordan han mente 121-FZ har redusert antallet hiv-forebyggingsprosjekter blant marginaliserte befolkningsgrupper i Russland:

Ved å motta utenlandsk finansiering risikerer du å bli oppført som utenlandsk agent, og det er en barriere for implementering av hiv-aktiviteter [i Russland]. NGO-er i Russland som tilbyr hiv-forebygging blant grupper som sprøytemisbrukere, sexarbeidere og menn som har sex med menn, kan telles på fingrene, og vi blir færre hvert år (intervju 020101, 2018).

En annen respondent, fra en organisasjon som tidligere har mottatt støtte fra blant annet Det globale fondet, beskrev hvordan de opplevde at myndighetene la press på organisasjonen gjennom 121-FZ:

\begin{abstract}
Akkurat nå er jeg veldig bekymret for loven om utenlandske agenter, de siste årene har vi bare hatt utenlandsk finansiering. Jeg er redd for at de [Justisministeriet] skal plassere oss på listen over utenlandske agenter. Jeg har akkurat vært på møte med dem, de intimiderte oss, truet med å stenge organisasjonen vår [...] Jeg hadde tatt med alle dokumentene våre, og jeg trodde jeg hadde gitt dem alt de trengte, men så ba de om enda flere dokumenter, så vi brukte hele helgen på å kopiere, og i morgen skal jeg ta det med til dem. [...] Organisasjonen vår pleide å være i stand til å kunne tilby flere tjenester til hiv-positive, men vi bruker mer og mer tid på rettslig beskyttelse (intervju 030103, 2018).
\end{abstract}

121-FZ har altså skapt en situasjon der organisasjoners eneste mulighet for risikofri finansiering er statstilskudd. Regimet har siden 2006 avholdt konkurranser der NGO-er kan søke om statlig finansiering (presidenttilskudd). ${ }^{23}$ Så lenge formelle

\footnotetext{
${ }^{23}$ Fram til 2017 ble tilskuddene distribuert gjennom flere ulike operatører med Samfunnskammeret som koordinator. I 2017 ble tildelingene omorganisert, og det nyopprettede "presidentfondet» administrerer nå tildelingene (Tass, 2017).
} 
søknadskrav er oppfylt, har prosjektene i teorien like muligheter til å få sine søknader innvilget. Tildelingene har imidlertid blitt kritisert for partiskhet og ugjennomsiktighet (Crotty, Hall \& Ljubownikow, 2014, s. 1256-1257). De siste årene har det vært en voldsom økning i både antall søknader og utdelte midler, ${ }^{24}$ noe som må ses i sammenheng med innføringen av 121-FZ. Imidlertid sa alle NGOrepresentantene jeg intervjuet, at deres organisasjoner fremdeles godtar utenlandske donasjoner, til tross for risikoen organisasjonene løper ved å motta slik finansiering. Statsstøtte er, som flere påpekte, vanskelig å få innvilget, og beløpene er for lave til at det sikrer kontinuitet i driften. En prosjektleder fra en presidentfondstøttet NGO forklarte hvordan mulighetene til utenlandsk finansiering i økende grad reduseres, og pekte på at statsstøtten de hadde mottatt, ikke kunne erstatte tidligere utenlandske donasjoner:

I 2016 omsatte organisasjonen vår for 35 millioner rubler, nå er det 20 millioner i året. Finansieringen fra utenlandske donorer har sunket, og vi har vært tvunget til å legge ned mange av prosjektene våre. For eksempel pleide vi å ha 18 rådgivere som selv er hivpositive [...] Nå har vi bare tre, de er betalt gjennom støtten vi fikk av presidentfondet (intervju 010201, 2018).

Hiv-/aidsorganisasjoner har tradisjonelt hatt begrenset tilgang til statlig finansiering (Gómez, 2015), men i 2017 mottok 23 hiv-/aidsprosjekter midler fra presidentfondet. Av disse tilbød over en tredel tjenester til mennesker som allerede er hiv-positive (Presidentfondet, 2018). ${ }^{25}$ To av mine intervjuobjekter, begge fra NGO-er som primært tilbyr sosial støtte og psykologisk rådgivning, oppga at de hadde mottatt presidentfondstøtte i 2017. Begge trakk fram viktigheten av å ha et prosjekt myndighetene anser som relevant, samt en detaljert og giennomarbeidet søknad (intervju 010102, 2018; intervju 010201, 2018). Den ene av disse NGO-representantene oppga også at han opplevde organisasjonens arbeidsvilkår som bedret de siste par årene (intervju 010102, 2018). Blant presidentfondstøttede forebyggingsprosjekter i 2017 var rundt 70 prosent av prosjektene rettet mot ungdom, og alle disse søknadene hadde referanser til hvordan prosjektene skulle promotere «sunn livsstil» og/eller «moralske og spirituelle verdier». Ingen prosjekter konsentrert rundt skadereduserende tiltak fikk sine søknader innvilget (Presidentfondet, 2018). En av mine respondenter forklarte hvordan han mener skjevheter i statstildelingene påvirker mangfoldet av hiv-/ aidsorganisasjoner i Russland:

Vi har søkt om støtte fra presidentfondet flere ganger, men søknadene våre har aldri blitt innvilget [...] Situasjonen er, etter min mening, veldig uheldig. Det er ikke noe kontinuitet i støtten til hiv-/aidsorganisasjoner fra statlig hold, særlig ikke for oss som jobber med hiv-forebygging i nøkkelgrupper [...] (intervju 020101, 2018).

\footnotetext{
${ }^{24}$ I 2013 mottok Samfunnskammeret 7308 søknader, et antall som var mer enn doblet i 2017. I 2012 ble 1,5 milliarder RUB utdelt i tildelingene (Samfunnskammeret, 2012, s. 54). Summen hadde økt til hele 7,8 milliarder RUB i 2018 (Presidentfondet, 2018).

${ }^{25}$ Tjenestene omfattet i hovedsak sosial støtte og psykologisk rådgivning.
} 
Nyere lovgivning reflekterer også den verdikonservative dreiningen og har hatt direkte negativ påvirkning på hiv-forebyggende arbeid. Et eksempel er «antipropaganda»lovendringen som trådte i kraft i 2013 (436-FZ). ${ }^{26}$ Endringen regulerer retten til distribusion av informasion som er i konflikt med "tradisjonelle russiske familieverdier» til barn under 18 år. Antipropagandatillegget har blant annet blitt brukt til å begrense hiv-forebygging blant ungdom. I 2017 protesterte en konservativ foreldregruppe i Arkhangelsk oblast mot undervisning de mente var «homofil propaganda» og dermed ulovlig. Årsaken var at læreren hadde kommentert at hiv kan smitte gjennom homoseksuell kontakt (Kolokol, Rossii 2017). I Tsjeljabinsk samme år konkluderte en rapport fra Roskomnadzor (medietilsynet) med at det lokale undervisningsopplegget "Grunnleggende hiv-kunnskap for 10. og 11. klasse» brøt 436-FZ. I rapporten konkluderes det med at undervisningen blant annet kan forårsake "seksuelle perversiteter som homofili» og "uopprettelig mental skade», og at oppleggets overordnede mål er "ødeleggelse av barndom» (Roskomnadzor, 2017, s. 14-16).

Tilgangen på andre internasjonalt anbefalte hiv-forebyggingstiltak blir også påvirket. Offisiell russisk motstand mot LAR er for eksempel befestet de siste årene, til tross for internasjonalt press og klager til Den europeiske menneskerettighetsdomstolen (Nekhezin, 2014). Holdningen har kommet til uttrykk blant annet ved uttalelser fra en visehelseminister om at LAR er «uforenelig med [russiske] nasjonale tradisjoner, lover og kulturelle verdier ${ }^{27}$ (Ria Novosti, 2016) og fra helseministeren om at "behandlingen dreper rusmisbrukere»" (Novosti OON, 2016). I 2016 forbød russiske myndigheter kondommerket Durex etter en angivelig registreringsfeil (Tass, 2016). Gennadij Onisjtsjenko, lege og tidligere leder av Roszdravnadzor (helsetilsynet), uttalte i den forbindelse at "kondomer ikke har noen relasjon til helse», men at forbudet derimot kunne tenkes «å løse noen demografiske problemer» (BBC, 2016). En rapport publisert av det statlige forskningsinstituttet RISI samme år, fremhevet hvordan "Moskva-modellen» for hiv-bekjempelse, som innebærer seksuelt avhold før ekteskapet og fokus på «et moralsk liv», er under sterkt internasjonalt press, samt at hiv/aids «blir brukt som et ledd i en informasjonskrig mot Russland» (Guzenkova, Petrovskaia \& Beloborodov, 2016, s. 51, 58). Under den offisielle presentasjonen av rapporten sa Ljudmila Stebenkova, leder for Moskvas helsekommisjon, at hun var lei av «alle mulige hint i pressen om at vi [Russland] angivelig har et høyt antall hivpositive», og at hun ikke var mot kondomer, men at hun ikke tror på deres "effektivitet mot hiv» (Tsjernykh, 2016a).

Aidsfornektere er også til stede i den offentlige debatten. Blant disse er legen Olga Kovekh, som i 2014 var invitert som ekspertkommentator i et helseprogram

\footnotetext{
${ }^{26}$ "Om beskyttelse av barn fra informasjon som er skadelig for deres helse og utvikling» er en 2013-lovendring i føderal lov nr. 436 fra 2010 (Føderal lov, 2010).

${ }^{27}$ Uttalelsen er fra Russlands visehelseminister Sergej Krajevoj i forbindelse med den russiske delegasjonens nei til LAR i FNs generalforsamling mai 2016.

${ }^{28}$ Uttalelsen er fra helseminister Viktoria Skvortsova under et intervju med FN i 2016.
} 
på den statlige TV-kanalen Tv Tsentr. Hun hevdet her at hiv ikke finnes, men at det er et virus i herpesfamilien som vestlige forskere «bestemte seg for å kalle hiv med mål om å tjene penger» (Tv Tsentr, 2014). Kovekh har også uttalt at hiv er en USAledet konspirasjon som har som mål å kontrollere verdens befolkning, drepe russere og tilrettelegge for hvitvasking av penger gjennom aidssentrene (Merzlikin, 2017b). Aidsfornektelse kan fremstå absurd, men informasjonsmangel og lav kvalitet på hiv-tjenester i Russland giør befolkningen mottakelig for aidsfornekteres budskap (Meylakhs, Rykov, Koltsova \& Koltsov, 2014, s. 1; Pape, 2014, s. 102). Feilinformasjon fører også til at hiv-smittede ikke behandles, som en ti år gammel jente fra St. Petersburg som rapporteres å ha dødd av aids i 2017, etter at foreldrene hennes skal ha nektet behandling fordi de trodde at aids var oppfunnet av legemiddelfirmaer (Merzlikin, 2017a).

\section{Diskusjon}

Denne artikkelen har sett på hvordan russisk hiv-politikk utformes i skjæringspunktet mellom modernisering og neopatrimonialisme, og hvilke konsekvenser denne dynamikken kan ha for forebygging og spredning av hiv i Russland i dag. Artikkelens datamateriale støtter at Putins kulturkonservative vending i 2012 kan ha svekket myndighetenes evne til å bygge en helhetlig og effektiv hiv-politikk. Jeg finner at særlig tre utviklingstrekk kan ha bidratt til dette.

\section{Lovendringer}

Innføringen av lovgivning som søker å redusere utenlandsk innblanding i Russland, særlig 121-FZ og tillegget om uønskede organisasjoner, har resultert $i$ at russiske og internasjonale sivile aktører presses til å nedskalere, stenge eller forlate landet, noe som har hatt negativ virkning på hiv-forebygging og andre hjelpetiltak. Sivilsamfunnet har, i fravær av statlig engasjement, vært hovedaktøren i Russlands hiv-respons, først og fremst som tilbyder av tjenester rettet mot marginaliserte nøkkelgrupper (Pape, 2014). Tjenestene som har forsvunnet med organisasjonene, tilbys som regel ikke av myndighetene, og dermed blir både antall og utvalg av hiv-programmer redusert. Skadereduserende tiltak er blant aktivitetene som i økende grad forsvinner, en situasjon som trolig vil øke smittespredning. Lov 121 har trolig også skapt et miljø der mange sivile aktører unngår aktiviteter som kan øke sjansene for rettslige eller finansielle problemer. ${ }^{29}$

Materialet mitt viser samtidig at enkelte ikke-statlige hiv-/aidsorganisasjoner har opplevd økt støtte etter 2016, hovedsakelig gjennom presidentfondbevilgninger.

\footnotetext{
${ }^{29}$ Lederen for en NGO som avslo intervjuforespørselen, forklarte at de hadde avsluttet alle sine tidligere prosjekter med skadereduserende formål etter at organisasjonen hadde blitt oppført som utenlandsk agent (e-postkorrespondanse 17.4.2018).
} 
Dette ser ut til å gjelde organisasjoner regimet opplever som nyttige eller aktverdige, enten fordi de anses å være leverandører av ønskede helse- og sosialtjenester, og/eller fordi de støtter regimets kulturkonservative retorikk. ${ }^{30}$ Det kan altså se ut som om det har foregått en slags finansiell omfordeling i løpet av Putins tredje presidentperiode. Penger som tidligere ble donert fra Russland til internasjonale aktører som Det globale fondet, og som deretter ble returnert til Russland i form av tilskudd til NGO-er utvalgt av globale aktører, har gradvis blitt kanalisert inn i nasjonale prosjekter direkte utpekt av regimet gjennom presidenttilskuddene.

\section{Verdikonservativ retorikk}

For det andre har tiltakende verdikonservativ og prorussisk retorikk ført til at russisk hiv-politikk beveger seg stadig lengre bort fra den "vestlige modellen» ${ }^{31}$ for hiv-bekjempelse, herunder internasjonale anbefalinger. Økende motstand mot veldokumenterte forebyggingstiltak, som seksualundervisning, LAR og programmer for utdeling av rene nåler og kondomer, er i denne sammenhengen særlig relevant. Konservative nasjonale aktører som motsetter seg internasjonale anbefalinger, synes å få økt tilgang på statlige strukturer, politikkutforming og finansiering, mens aktører som tilbyr internasjonalt anbefalte tiltak, ikke mottar støtte eller i verste fall blir rettslig forfulgt. Utviklingen er trolig uheldig, da hiv-epidemien i realiteten neppe kan stanses uten å inkludere nøkkelgrupper som sprøytemisbrukere (UNAIDS, 2016b). En liberalisering av russisk hiv-politikk vil imidlertid trolig kunne skade forholdet til innflytelsesrike konservative aktører, som Putin etter 2012 har basert en del av sin politiske legitimitet og dominans på. Bevaring av disse forholdene, for eksempel forholdet til den russisk-ortodokse kirken, ser altså ut til å prioriteres framfor «kontroversielle» evidensbaserte tiltak. Et sentralt spørsmål i denne sammenhengen er hvorvidt prioriteringen egentlig tjener russiske interesser.

Antivestlig retorikk og regimets rolle som beskytter av tradisjonelle verdier kan også utnyttes for å dekke over konkrete politiske og/eller økonomiske utfordringer med å ta tak i hiv-problematikken. I den offentlige debatten har både konvensjonell hiv-forebygging og russiske smittestatistikker blitt avvist som "vestlig propaganda", eller som en del av en «informasjonskrig mot Russland» (Guzenkova et al., 2016; Frolov, 2016). Inkludering av aidsfornektere i den offentlige diskursen kan i denne sammenhengen også trekkes fram. Videre kan også den økende konfrontasjonen med Vesten siden 2014 antas å ha styrket antivestlige stemmer.

\footnotetext{
${ }^{30}$ Blant hiv-/aidsprosjekter som i 2017 ble tildelt midler fra presidentfondet, er det en rekke tiltak rettet mot kvinner, barn, demografisk vekst, seksuelt avhold før ekteskapet og heteronormative par i tillegg til flere behandlings- og forebyggingsprosjekter i samarbeid med den russisk-ortodokse kirken. Organisasjonen som i intervju oppga økt støtte, har russisk-ortodoks profil.

${ }^{31}$ I RISI-rapporten fra 2016 peker forfatterne på to hovedmodeller for hiv-bekjempelse, den ene konservativ (Moskva-modellen) og den andre liberal (den vestlige modellen) (Guzenkova et al., 2016, s. 47).
} 


\section{Neopatrimonialisme}

Til sist vil jeg trekke fram sementering av neopatrimonialisme i Russland etter 2012 som et tredje utviklingstrekk som kan ha negative konsekvenser for Russlands evne til å redusere hiv-spredning. Neopatrimonialisme som styreform gjør det vanskelig å gjennomføre vellykkede reformer (Gelman, 2016, s. 436). Reformer er imidlertid trolig nødvendig for at regimet skal kunne få hiv-spredningen under kontroll. Økt statlig finansiell investering $i$ helseprogrammer vil heller ikke være effektivt uten at man samtidig innfører reformer som effektiviserer og forbedrer de tjenestene som tilbys (Verdensbanken, 2008, s. 9).

\section{Veien videre}

Det eksisterer i dag både rettslige, økonomiske, sosiale og administrative barrierer for effektiv håndtering av hiv-epidemien i Russland. Årlig økning i nye infeksjonstilfeller har de siste årene ligget stabilt på 10-15 prosent, noe som tydeliggiør behovet for hiv-politiske reformer. Blant annet kan konservativ narkotika- og NGO-lovgivning, høye medikamentpriser og legemiddelmangel, stigma, diskriminering og mangel på kunnskap og informasjon, ujevn tilgang på aidsklinikker og lav behandlingsdekning trekkes fram som sentrale svakheter ved dagens situasjon.

Gelman og Starodubtsev (2016, s. 114) peker på at en kombinasjon av fire kriterier må være oppfylt for at innføringen av russiske reformer skal kunne lykkes: 1) Presidenten må personlig anse den aktuelle reformen som en prioritet, 2) interessegrupper som jobber mot reformen, må holdes på avstand, 3) politiske endringer må implementeres raskt, og 4) reformen må gi umiddelbare resultater.

Vellykket innføring av hiv-reformer vil altså kreve at Putin anser endringer i Russlands hiv-politikk som en personlig prioritet. Putin viste så vidt interesse for hiv på 2000-tallet, men har siden forholdt seg relativt taus. Videre viser han liten evne til, eller interesse for, å holde interessegrupper som motsetter seg evidensbasert hivrespons, på avstand. Muligheten for raske politiske endringer kompliseres av at russisk politikkutforming er preget av komplekse og ineffektive forhandlinger og avtaler, hvor personlig gevinst ofte er hovedmålet (Gelman, 2016, s. 436). Reformer som kan produsere umiddelbare resultater, vanskeliggiøres av manglende tilgang på effektiv ART i Russland, som er det viktigste smittereduserende tiltaket.

Mens internasjonalt press på Russland så ut til å ha en viss innvirkning på regimets fokus og prioriteringer før 2012, illustrert ved hendelser som Russlands pionerrolle i G8s hiv-samarbeid og donasjoner til global hiv-/aidsbistand, er det vanskelig å se at slikt press har hatt virkning etter 2012. Ved å være passive unngår myndighetene upopulære avgjørelser og forebyggings- og behandlingsutgifter på kort sikt, men på lengre sikt kan konsekvensen bli en betydelig samfunnsøkonomisk belastning. Et økende antall mennesker med behov for behandling og oppfølging vil sannsynligvis legge press på det russiske velferdssystemet, og de demografiske utfordringene Russland allerede opplever, kan forverres som følge av aidsrelaterte dødsfall. I hovedsak 
er det innbyggere i arbeidsfør alder som smittes, noe som igjen undergraver den russiske økonomiens internasjonale konkurransedyktighet (Pape, 2014). Lanseringen av den første russiske hiv-strategien på femten år i 2016 viser imidlertid at det finnes politisk bevissthet rundt hiv i Russland. Likevel er det, innenfor dagens politiske rammer, vanskelig å se for seg at strategien vil kunne forbedre den epidemiologiske situasjonen i betydelig grad.

\section{Litteratur}

U.S. Department of Health and Human Services (2015). A timeline of HIV/AIDS. Hentet 5. september 2017 fra https://www.hiv.gov/sites/default/files/aidsgov-timeline.pdf

Aleksejev, M. (2010, 13. mai). Letsjenije bez profilaktiki. Medportal.ru. Hentet 20. oktober 2017 fra https:// medportal.ru/mednovosti/main/2010/05/13/hivrus/

BBC (2016, 17. juni). Pretenzii Rossii k prezervativam Durex: stoit li bespokoitsia. Hentet 12. januar 2018 fra http://www.bbc.com/russian/other_news/2016/06/160617_tr_durex_russia_condoms

Bobrik, A. \& Twigg, J. L. (2006). HIV/AIDS in Russia. I J. Twigg (Red.), HIVIAIDS in Russia and Eurasia. Volume 2 (s. 1-40). New York: Palgrave Macmillan.

Boronov, A. (2017, 15. februar). Lekarstv ot VITSJ ne khvatajet v 20 regionakh RF. Kommersant. Hentet 04. april 2018 fra https://www.kommersant.ru/doc/3219515

Bowen, G. (2009). Document analysis as a qualitative research method. Qualitative Research fournal, 9 (2), 27-40.

Bryman, A. (2016). Social research methods. Oxford: Oxford University Press.

Clark, F. (2016). Gaps remain in Russia's response to HIV/AIDS. The Lancet, 388 (10047), 857-58.

Crotty, J., Hall, S. M. \& Ljubownikow, S. (2014). Post-Soviet civil society development in the Russian Federation: The impact of the NGO law. Europe-Asia Studies, 66 (8), 1253-69.

Det føderale aidssenteret (2016). Spravka VITSJ-infektsija v Rossijskoj Federatsii na 31 dekabrja 2016 g. Hentet 25. november 2018 fra http://itpcru.org/2017/06/21/spravka-vich-infektsiya-v-rossijskoj-federatsii-na-31dekabrya-2016-g/

Det føderale aidssenteret (2018). Spravka VITSJ-infektsija v Rossijskoj Federatsii v pervom polugodii 2018 g.

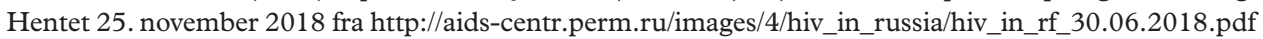

Det føderale aidssenteret (u.å.). Statistika. Hentet 25. november 2018 fra http://www.hivrussia.ru/stat/index. shtml

Det globale fondet (2010). Global Fund third voluntary replenishment 2011-2013. Pledges for 20112013 at 5 October 2010. Hentet 22. november 2018 fra https:/www.theglobalfund.org/media/1441/ replenishment_2010newyorkmeetingpledges_table_en.pdf

Det globale fondet (2017). Pledges and contributions. Hentet 05. desember $2018 \mathrm{fra} \mathrm{https://www.theglobalfund.}$ org/media/1119/core_pledgescontributions_list_en.xlsx

DHHS (1987). Approval of AZT. Hentet 22. november 2018 fra https://aidsinfo.nih.gov/news/274/approval-of-azt

Field, M. G. (2004). HIV and AIDS in the former Soviet bloc. The New England fournal of Medicine, 351, $117-20$.

Fight against infectious diseases (2006). Hentet 19. oktober $2017 \mathrm{fra} \mathrm{http://en.kremlin.ru/supplement/3716}$

Flikke, G. (2016). Resurgent authoritarianism: the case of Russia's new NGO legislation. Post-Soviet Affairs, 32 (2), 103-31.

FN (2001). Secretary-General proposes global fund for fight against HIV/AIDS and other infectious diseases at African leaders summit. Hentet 02. oktober 2017 fra http://www.un.org/press/en/2001/SGSM7779R1. doc.htm

Føderal lov (1998). Federalnyj zakon ot 08.01.1998 g. No 3-FZ. Hentet 01. august 2019 fra http://kremlin. $\mathrm{ru} / \mathrm{acts} / \mathrm{bank} / 11860$

Føderal lov (2006). Federalnyj zakon ot 10.01.2006 g. No 18-FZ. Hentet 01. august 2019 fra http://www. kremlin.ru/acts/bank/23347

Føderal lov (2010). Federalnyj zakon ot 29.12.2010 g. No 436-FZ. Hentet 29. oktober 2018 fra http://kremlin. $\mathrm{ru} / \mathrm{acts} / \mathrm{bank} / 32492$

Føderal lov (2012). Federalnyj zakon ot 20.07.2012 g. No 121-FZ. Hentet 01. august 2019 fra http://kremlin. $\mathrm{ru} / \mathrm{acts} / \mathrm{bank} / 35748$ 
Føderal lov (2015). Federalnyj zakon ot 23.05.2015 g. No 129-FZ. Hentet 01. august 2019 fra http://www. kremlin.ru/acts/bank/39720

Frøland, S. (2017). Hiv-infeksjon. Store medisinske leksikon. Hentet 04. desember 2018 fra https://sml.snl.no/ hiv-infeksjon

Frolov, O. (2016, 06. juni). Krepkaja semja - lutsjsjaja zasjtsjita ot SPIDa. Komsomolskaja Pravda. Hentet 01. desember 2017 fra https:/www.msk.kp.ru/daily/26537/3554447/

Gelman, V. \& Starodoubtsev, A. (2016). Opportunities and constraints of authoritarian modernisation: Russian policy reforms in the 2000s. Europe-Asia Studies, 68 (1), 97-117.

Gelman, V. (2016). The vicious circle of post-Soviet neopatrimonialism in Russia. Post-Soviet Affairs, 32 (5), 455-73.

Gilbert, L. (2016). Crowding out civil society: State management of social organizations in Putin's Russia. Europe-Asia Studies, 68 (9), 1553-78.

Gómez, E. J. (2015). Understanding the BRIC response to AIDS: political institutions, civil society, and historical policy backlash in comparative perspective. Commonwealth $\mathcal{E}$ Comparative Politics, 53 (3), 315-40.

Guzenkova, T. S., Petrovskaia, O. V. \& Beloborodov, I. I. (2016). Analititsjeskij doklad. Sotsialnyje aspekty protivodejstvija vitsj-infektsiii v megapolisakh (na primere Moskvy). Hentet 05. desember 2018 fra https://riss.ru/wp-content/uploads/2016/06/Doklad_1.3.pdf

Hale, H. E. (2015). Patronal politics. Eurasian regime dynamics in a comparative perspective. New York: Cambridge University Press.

Hebel, C. (2016, 02. desember). Epidemija VITSJ v Rossii: Irina moltsjit, Marina boretsja. Der Spiegel. Hentet 11. april $2018 \mathrm{fra} \mathrm{https://inosmi.ru/social/20161202/238327106.html}$

Helseministeriet (2001). Postanovlenije Pravitelstva RF №790 ot 13 nojabrja 2001 g. Hentet 06. oktober 2017 fra https://www.rosminzdrav.ru/documents/7998-postanovlenie-pravitelstva-rf-790-ot-13-noyabrya-2001-g

HRRCenter (2018).VITSJ-servisnyj organizatsii Rossii nakhodjatsja pod davlenijem. Hentet 20. april 2018 fra http://www.hrrcenter.ru/news/detail.php?ID=2295

Ingram, M. (1996). Russia is on brink of AIDS epidemic. BMF, 313, 252.

INSOR (2010). Rossija XXI Veka: Obraz zjelaemogo zavtra. Hentet 02. desember 2018 fra http://www.insorrussia.ru/files/Obraz_gel_zavtra_0.pdf

Interfax (2018, 10. juni). Fond Timura Islamova iz Tatarstana vkljutsjil v reestr NKO-inoagentov. Hentet 01. august 2019 fra https://www.interfax.ru/russia/620486

Justisministeriet (2018a). O dejatelnosti nekommertsjeskykh organizatsii; Svedenija rejestra NKO, vypolnjajusjtsjykh funktsii inostrannogo agenta. Hentet 07. desember 2018 fra http://unro.minjust.ru/ NKOForeignAgent.aspx

Justisministeriet (2018b). Peretsjen inostrannykh i mezjdunarodnykh nepravitelstvennykh organizatsij, dejatelnost kotorykh priznana nezjelatelnoj na territorii Rossijskoj Federatsii. Hentet 07. desember 2018 fra http://minjust.ru/ru/activity/nko/unwanted

Kirton, J., Kulik, J. \& Bracht, C. (2014). Generating global health governance through BRICS summitry. Contemporary Politics, 20 (2), 146-62.

Knight, L. (2008). UNAIDS: The first 10 years. Hentet 04. september 2017 fra http://data.unaids.org/pub/ report/2008/jc1579_first_10_years_en.pdf

Kolokol Rossii (2017, 19. april). Sjestiklassnikov Arkhangelskoj oblasti “poradovali” urokami seks- i narkoprosveta. Hentet 03. november 2017 fra http://kolokolrussia.ru/sovetuem-pochitat/shestiklassnikovarhangelskoy-oblasti-poradovali-urokami-seks-i-narkoprosveta

Levi, J., Raymond, A., Pozniak, A., Vernazza, P., Kohler, P. \& Hill, A. (2016). Can the UNAIDS 90-90-90 target be achieved? A Systematic analysis of national HIV treatment cascades. BMF Global Health, 1 (2), 1-10.

Marx, J. L. (1984). Strong new candidate for AIDS agent. Science, 224 (4648), 475-77.

Medvedev, Z. (1990a). Evolution of AIDS policy in the Soviet Union. I. Serological screening 1986-7. BMF, 300 (6728), 860-61.

Medvedev, Z. (1990b). Evolution of AIDS policy in the Soviet Union. II. The AIDS epidemic and emergency measures. BMF, 300 (6729), 932-34.

Merzlikin, P. (2017a, 30. august). V Peterburge umerla devotsjka s VITSJ-infektsiej. Jejo roditeli byli uvereny, tsjto takogo zabolevanija net. Meduza. Hentet 09. januar 2018 fra https://meduza.io/feature/2017/08/30/ v-peterburge-umerla-devochka-s-vich-infektsiey-ee-roditeli-byli-uvereny-chto-takogo-zabolevaniya-net

Merzlikin, P. (2017b, 02. oktober). Doktor Smert' i jejo druzja. Kto v Rossii sklonjajet ljudej k VITSJdissidentstvu - i kto s nimi boretsja. Meduza. Hentet 17. januar fra https://meduza.io/feature/2017/10/02/ doktor-smert-i-ee-druzya 


\section{8 | JULIE HELSETH UDAL}

Meylakhs, P., Rykov, Y., Koltsova, O. \& Koltsov, S. (2014). An AIDS-denialist online community on a Russian social networking service: Patterns of interactions with newcomers and rhetorical strategies of persuasion. fournal of Medical Internet Research, 16 (11), 1-11.

Nekhezin, V. (2014, 04. juni). Rossijskie narkomany borjutsja za metadon v ESPTSJ. BBC. Hentet 11. januar

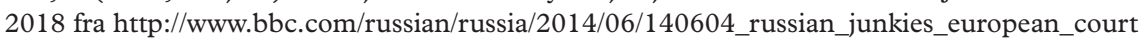

NIC (2002). The next wave of HIV/AIDS: Nigeria, Ethiopia, Russia, India and China. Hentet 22. november 2017 fra https://fas.org/irp/nic/hiv-aids.html

Novosti OON (2016, 17. juni). Ministr zdravookhranenija Rossii: 'zamestitelnaja terapija' opasneje geroina. Hentet 11. januar 2018 fra https://news.un.org/ru/audio/2016/06/1034471

OECD (2018). Net ODA (indicator). Hentet 16. november 2018 fra https://www.oecd-ilibrary.org/ development/net-oda/indicator/english_33346549-en

OUS (2018). Legemiddelassistert rehabilitering (LAR). Hentet 07. desember 2018 fra https://oslouniversitetssykehus.no/behandlinger/legemiddelassistert-rehabilitering-lar-

Pape, U. (2014). The politics of HIVIAIDS in Russia (BASEES/Routledge Series on Russian and East European Studies). London/New York: Routledge.

Presidentfondet (2018). Hovedside. Hentet 06. desember 2018 fra https:/президентскиегранты.рф

Putin, V. (2003). Poslanije Federalnomu Sobraniju Rossijskoj Federatsii. Hentet 12. oktober 2017 fra http:// kremlin.ru/events/president/transcripts/21998

Putin, V. (2006). Vstupitelnoje slovo na zasedanii prezidiuma Gosudarstvennogo soveta 'O neotlozjnykh merakh po borbe s rasprostranenijem VITSJ-infektsii v Rossijskoj Federatsii'. Hentet 12. oktober 2017 fra http://kremlin.ru/events/president/transcripts/23547

Qui, L. (2017, 12. desember). Fingerprints of Russian disinformation: From AIDS to fake news. The New York Times. Hentet 02. november 2018 fra https:/www.nytimes.com/2017/12/12/us/politics/russiandisinformation-aids-fake-news.html

Regjeringen (2016). Razporjazjenije ot 20 oktjabrja 2016 g. No 2203-r. Hentet 04. oktober 2018 fra http:// static.government.ru/media/files/cbS7AH8vWirXO6xv7C2mySn1JeqDIvKA.pdf

Ria Novosti (2012, 09. oktober). JUNISEF zaversjil programmy v RF yesjtsjo v 2011 godu, soobsjtsjili v organizatsii. Hentet 13. oktober 2018 fra https://ria.ru/society/20121009/769934561.html

Ria Novosti (2016, 30. mai). RF na Genassambleje OON ne podderzjit 'metadonovuju terapiju' pri letsjenii VITSJ. Hentet 07. September 2018 fra https://ria.ru/society/20160530/1440842604.html

Robinson, N. (2017). Russian neo-patrimonialism and Putin's 'cultural turn'. Europe-Asia Studies, 69 (2), $348-66$.

Roskomnadzor (2017). Zakljutsjenije kompleksnoj eksperizy. Hentet 05. desember 2018 fra https://rkn.gov.ru/ docs/JEkspertnoe_zakljuchenie_Tatchmamedova-KHmurova.pdf

Rospotrebnadzor (2018). Sovmestnyj kommentarij Rospotrebnadzora i Minzdrava Rossii o zabolevajemosti VITSJ/SPID v Rossii. Hentet 05. desember 2018 fra http://rospotrebnadzor.ru/about/info/news/news_ details.php?ELEMENT_ID=10919

Rosstat (2010). Zabolevajemost naselenija alkogolizmom i narkomanijej. Hentet 09. november 2018 fra http:// bi.gks.ru:8080/DDB/showcharts.jsp?report=nas04\&project=BIPortal_cen_2.bip

Samfunnskammeret (2012). Doklad o sostojanii grazjdanskogo obsjtsjestva v Rossijskoj Federatsii za 2012 god. Hentet 01. august 2018 fra https://www.oprf.ru/files/doklad_grazdanskoe_obshestvo.pdf

Sharma, A., Lioznov, D. \& DeHovitz, J. A. (2008). Russian Federation. I D. Celentano \& C. Beyrer (Red.), Public health aspect of HIVIAIDS in low and middle income countries. Epidemiology, prevention and care (s. 531-55). New York: Springer.

Shishkin, S. (2013). Russia's health care system: Difficult path of reform. I M. Alexeev \& S. Weber (Red.), The Oxford Handbook of the Russian Economy (s. 748-74). New York: Oxford University Press.

SIBALT (2016). Otkrytoje pismo Pravlenija OROO Tsentr 'SIBALT'. Hentet 18. oktober 2018 fra http:// www.sibalt.org/news/102-otkrytoe-pismo-pravleniya-oroo-tsentr-sibalt

Tass (2016, 16. juni). Rosdravnadzor zapretil prodazju britanskikh prezervativov Durex. Hentet 3. desember 2018 fra https://tass.ru/obschestvo/3372289

Tass $(2017,21$. november). Prezidentskije granty dlja NKO. Dose. Hentet 26. februar 2018 fra http://tass.ru/ info/4483700

Taylor, B. D. (2011). State building in Putin's Russia. New York: Cambridge University Press.

Tsjernykh, A. (2016a, 31. mai). V SPIDe ne nasjli nitsjego russkogo. Kommersant. Hentet 15. november 2018 fra https://www.kommersant.ru/doc/3000818

Tsjernykh, A. (2016b, 19. april). Sud vo vremja epidemii. Kommersant. Hentet 17. april 2018 fra https://www. kommersant.ru/doc/2967485 
Tv Tsentr (2014, 26. juni). Doktor I., 'ZPPP-SPID'. Hentet 09. januar 2018 fra http://www.tvc.ru/channel/ brand/id/28/show/episodes/episode_id/33528/?page $=21$

Twigg, J. L. \& Skolnik, R. (2005). Evaluation of the World Bank's assistance in responding to the AIDS epidemic: Russia case study. Hentet 16. oktober 2017 fra http://siteresources.worldbank.org/EXTHIVAIDSIEG/ Resources/hiv_russia_case_study.pdf

Twigg, J. L. (2010). Russia's global health outlook: Building capacity to match aspirations. I K. E. Bliss (Red.), Key players in global health: How Brazil, Russia, India, China and South Africa are influencing the game (s. 34-40). Washington, DC: Center for Strategic and International Studies.

Udal, J. H. (2018). Lost in space? A case study of the HIV epidemic in neo-patrimonial Russia. Masteroppgave. Institutt for litteratur, områdestudier og europeiske språk. Oslo: Universitetet i Oslo.

UNAIDS (1996). The status and trends of the global HIV/AIDS pandemic. Hentet 12. september 2017 fra http://data.unaids.org/publications/irc-pub04/statuskme_en.html

UNAIDS (2008). 2008 Report on the global AIDS epidemic. Hentet 05. desember 2018 fra http://www. unaids.org/sites/default/files/media_asset/jc1510_2008globalreport_en_0.pdf

UNAIDS (2016a). Prevention gap report. Hentet 26. oktober 2017 fra http://www.unaids.org/sites/default/ files/media_asset/2016-prevention-gap-report_en.pdf

UNAIDS (2016b). Ending AIDS by 2030 requires investment in harm reduction for people who inject drugs. Hentet 07. desember 2018 fra http://www.unaids.org/en/resources/presscentre/featurestories/2016/ october/20161010_harmreduction

UNAIDS (2018a). Miles to go. Hentet 05. desember $2018 \mathrm{fra} \mathrm{http://www.unaids.org/sites/default/files/media}$ asset/miles-to-go_en.pdf

UNAIDS (2018b). Resource mobilization. Hentet 03. desember 2018 fra http://www.unaids.org/en/ourwork/ exo/resourcemobilization

UNDCP (2000). Global illicit drug trends 2000. Hentet 19. september 2017 fra https://www.unodc.org/pdf/ report_2000-09-21_1.pdf

USAID (2012). USAID in Russia. Hentet 01. april 2018 fra https://www.usaid.gov/news-information/factsheets/usaid-russia

Verdensbanken (2008). Better outcomes through health reforms in the Russian Federation: the challenge in 2008 and beyond. Hentet 28. oktober 2018 fra https:/www.who.int/management/country/rus/ BetterOutcomesReformsRussia.pdf

Vzgljad-info (2016, 14. april). Professor nazval ‘Sotsium' utsjastnikom gibridnoj vojny protiv Rossii. Hentet 16. februar 2018 fra http:/www.vzsar.ru/news/2016/04/14/professor-nazval-sociym-ychastnikom-gibridnoivoiny-protiv-rossii.html

WHO (2013). Consolidated guidelines on the use of antiretroviral drugs for treating and preventing HIV infection. Hentet 26. september 2017 fra http://apps.who.int/iris/bitstream/10665/85321/1/9789241505727_eng. pdf

WHO (2015). Overview of financing - 31 December 2015. Hentet 05. desember 2018 fra http://extranet.who. int/programmebudget/Biennium2014/Flow

WHO (2017). Financing of global programme of work 2014-2019. Hentet 02. april 2018 fra http://open.who. int/2016-17/budget-and-financing

Zvezdina, P. (2016, 25. november). V pravitelstve otkazalis ot vydelenija 70 mlrd rub. na borbu c VITSJ. RBK. Hentet 25. oktober 2017 fra http://www.rbc.ru/politics/25/01/2017/5888ad049a79470bb2887762 